\title{
某事業所男性従業員における高尿酸血症と 自覚症状および生活習慣との関連性
}

\begin{tabular}{|c|c|c|}
\hline${\text { 真治 }{ }^{1)}}$ & 伊藤 & 宜則 2$)$ \\
\hline 義隆1) & 渡邊 & 悟1) \\
\hline
\end{tabular}

要 旨 定期健診受診男性 348 名を対象として, 高尿酸血症と自覚症状および生活習慣と の関連性について検討した。対象者は, 某製鋼事業所の年齢 39 歳から 60 歳の技術系従業 員 207 名と事務系従業員 141 名である。

自覚症状の高尿酸血症に対するオッズ比は, イライラ感を有するもので $2.23(95 \%$ 信 頼区間：1.32～3.77），疲労感を有するもので $1.66(95 \%$ 信頼区間：1.02〜2.73）であっ た。生活習慣の高尿酸血症に対するオッズ比は, 外食習慣を多く有するもので 2.58 (95\%信頼区間：1.32〜 5.03)，アルコール捸取の多いもので 2.50 (95\%信頼区間：1.26 〜4.96) であった。年齢, 職種, 喫煙および飲酒習慣, BMI, 血清総コレステロール, クレアチニン, GPT 活性などを調整した際の高尿酸血症に対するオッズ比は, 血清レチ ノール值の高值者で 4.45 (95\%信頼区間：2.24～8.86)， $\alpha^{-}$トコフェロールの高值者で 2.22 （95\%信頼区間：1.09〜 4.63）であった。一方，血清 $\beta$-カロテン值の高値者におけ るオッズ比は, 0.49 (95\%信頼区間：0.25〜0.96）であった。

これらの結果は, イライラ感, 疲労感などの自覚症状, 外食, 飲酒などの生活習慣が高 尿酸血症の危険要因となり, $\beta$-カロテンを多く含有する食品（有色野菜や果物類）摂取 が予防要因となる可能性を示唆した。

キーワード : 高尿酸血症, 自覚症状, 生活習慣, カロテノイド, オッズ比

\section{緒言}

尿酸は核酸の一つであるプリン体の代謝産物で あり，腎臓を介して体外に排泄されるが，産生過 剩や排泄低下など尿酸代謝バランスの乱れに伴 い，高尿酸状態が生ずる ${ }^{1,2)}$ 。尿酸は難溶性であ り, 組織中などで析出しやすく, 主に足のつけね などに激しい痛みなどの自覚症状が伴う痛風（痛 風性関節炎発作）を発症する ${ }^{1,2)}$ 。痛風は，高度 経済成長期以降に疾病頻度の増加が目立ち, 1995 年の国民生活基礎調査では約 42 万人程度とされ, 痛風の増加は特に過食, 運動不足等に伴う肥満,

1）大同産業医学研究所

2）藤田保健衛生大学衛生学部公衆衛生学教室
ビールなどのアルコール飲量の増加, 食生活の欧 米化に伴う日常食生活習慣の変化に依存すること が大きいとされている3 7)。また，尿酸高值者で はその後の死亡危険度が高く，尿酸値の高い者ほ ど危険度が大きい8)。したがって，健康診断受診 者に対する高尿酸血症予防のためには，規則正し い食生活習慣の習得を目指した保健指導や栄養指 導が強く求められる。ここでは, 男性の定期健康 診断受診者の血清尿酸值から見た，尿酸高值者の 自覚症状や野菜摂取などの日常食生活習慣等の特 徵について検討し, 若干の知見を得たので報告す る。 


\section{対象および方法}

対象は, 某事業所の平成 11 年度定期健康診断 受診者のうち，39〜60 歳までの男性 521 名から, 健康診断結果で精密検査を要する者，および投薬 などの治療中の者を除いた 348 名である。その対 象者の職種別受診者数は, 生産現場業務を主とす る技術系従業員 207 名（平均年齢：52.5 土5.3 歳) と，本社で事務的業務を主とする事務系従業 員 141 名（平均年齢： $53.2 \pm 5.1$ 歳）である。生 化学的検査は健康診断時に空腹時採血した血液を 試料として, 自動分析機（日立 7350 型）で測定 した。尿酸值測定法は酵素法を用い, 尿酸高值者 は血清尿酸值 $7.0 \mathrm{mg} / \mathrm{d} l$ 以上の者とし, それ未 満の者を尿酸正常者とした ${ }^{2,10)}$ 。血清 $\alpha$-カロテン 值 (以下 $\mathrm{AC}$ ), $\beta$-カロテン值 $(\mathrm{BC})$, リコピン 值 (LY), $\beta$-クリプトキサンチン值 $(\mathrm{CR})$, ゼ アキサンチン\&ルテイン值 (ZL), カンタキサン チン值 (CX) およびレチノール值 (RE), $\alpha^{-}$卜 コフェロール值（AT）などは, 高速液体クロマ トグラフィで分画測定した ${ }^{111}$ 。ZL はゼアキサン チン值とルテイン值の和, 総カロテン值 (TCR) は $\mathrm{AC}, \mathrm{BC}$ 抢よび $\mathrm{LY}$ の和, 総キサン トフィル值 (TXP) は CY, ZL, CX の和, プ ロビタミン $\mathrm{A}$ 值 (PVA) は $\mathrm{AC}, \mathrm{BC}$ 打よび $\mathrm{CR}$ の和, 総カロテノイド值 (TCA) は TCR, TXPの和とした。

既往歴, 現病歴, 家族歴, 自覚症状および食生 活習慣は自記式問診票を定期健康診断 $2 \sim 3$ 週間 前に配布し, 健康診断受診当日に担当保健婦がそ の内容を確認する方式で調査した ${ }^{12)}$ 。自記式問診 票の調査項目は，1）本人おょび父親, 母親, 兄 弟の各疾病既往歴の有無, 2) 肩こり, 胸の痛み, 喉の乾き, 胃の痛み, 焦燥感, 疲労感, 不眠感な どの自覚症状の有無, 3) 夜トイレに起きるなど の行動の有無,4）1回/週以上の運動習慣の有
無，5）間食，夜食の有無，6）3回/週以上の外 食の有無，7）野菜摂取嗜好の有無，8）魚類より 肉類摂取嗜好の有無，9）喫煙および飲酒習慣の 有無などである。

統計解析は, 各自覚症状および食生活習慣の有 無別の尿酸高值者と尿酸正常者のオッズ比と, 95\%信頼区間をロジスティック回帰分析法 ${ }^{13)}$ 求めて比較した。また, 技術系従業員, および事 務系従業員の血清カロテノイド值分布を 3 等分 (低值群, 中間値群, 高值群) し, 血清カロテ) イド値の低值群における, 尿酸高值者と尿酸正常 者のオッズ比を 1.0 とした際の中間值群, 高值群 のオッズ比と $95 \%$ 信頼区間を求めた。モデル 1 は年齢, および職種を調整, モデル 2 は, 年齢, 職種, 喫煙と飲酒習慣の有無, BMI, 総コレス テロール值，クレアチニン值および GPT 值を調 整してそれぞれ算出した。統計解析プログラムは Mac 版 StatView 5.0 統計パッケージを用いて 行った。

\section{結果}

対象者の特性は表 1 に示したように 50 歳代の 受診者数は, 技術系事務系従業員共に $70 \%$ 程度 を占めた。職種別での尿酸高值者割合は技術系従 業員 $35.3 \%$, 事務系従業員 $34.8 \%$ と両者の割合 は近似した。喫煙者割合は技術系従業員 $72.9 \%$, 事務系従業員 $68.1 \%$ あ゙り, 技術系事 務系従業員共に尿酸高值者の喫煙率は $35 \%$ 程度 であった。習慣的飲酒者割合は技術系従業員 $77.3 \%$, 事務系従業員 $85.1 \%$ ありり, 事務系従 業員で飲酒率が高い傾向を示し, 尿酸高値者の飲 酒率は同率であった。

対象者の年齢, BMI, 血清成分值, 総カロテ ノイド值について表 2 に示す。職種別での尿酸高 值者平均年齢では事務系従業員 51.4 歳, 技術系 従業員 51.8 歳と近似したが, それぞれの職種で

表 1 調査対象者の特性

\begin{tabular}{|c|c|c|c|c|c|c|c|c|c|c|c|}
\hline \multirow{2}{*}{\multicolumn{2}{|c|}{ 項 }} & \multirow[b]{2}{*}{ 目 } & \multicolumn{3}{|c|}{ 全体 } & \multicolumn{3}{|c|}{ 技術系従 業員 } & \multicolumn{3}{|c|}{ 事 務 系 従 業 } \\
\hline & & & $\begin{array}{c}\text { 総数 } \\
\text { 例数 }(\%)\end{array}$ & \begin{tabular}{|c} 
尿酸正常値者 \\
例数 $(\%)$
\end{tabular} & $\begin{array}{c}\text { 尿酸高値者 } \\
\text { 例数 }(\%) \text { ) }\end{array}$ & $\begin{array}{c}\text { 総数 } \\
\text { 例数 }(\%)\end{array}$ & $\begin{array}{c}\text { 尿酸正常値者 } \\
\text { 例数 }(\%)\end{array}$ & $\begin{array}{c}\text { 尿酸高値者 } \\
\text { 例数 }(\%)\end{array}$ & $\begin{array}{c}\text { 総数 } \\
\text { 例数 }(\%)\end{array}$ & $\begin{array}{c}\text { 㽷酸正常値者 } \\
\text { 例数 }(\%)\end{array}$ & $\begin{array}{c}\text { 尿酸高値者 } \\
\text { 列数 }(\%)\end{array}$ \\
\hline \multirow{2}{*}{ 年 } & 齢 & 4 & $93(26.7)$ & $53(57.0)$ & $40(43.0)$ & $58(28.0)$ & $32(55.2)$ & $26(44.8)$ & $35(24.8)$ & $21(60.0)$ & $14(40.0)$ \\
\hline & 醖 & $50-6$ & 255 (73. 3) & $173(67.8)$ & $82(32.2)$ & $149(72.0)$ & $102(68.5)$ & $47(31.5)$ & $106(75.2)$ & $71(67.0)$ & $35(33.0)$ \\
\hline \multirow{2}{*}{\multicolumn{2}{|c|}{ 堛好習慣 }} & 喫煙者 & $247(71.0)$ & $161(65.2)$ & $86(34.8)$ & $151(72.9)$ & $98(64.9)$ & $53(35.1)$ & $96(68.1)$ & $63(65.6)$ & $33(34.4)$ \\
\hline & & 習慣的飲酒者 & $280(80.5)$ & $175(62.5)$ & $105(37.5)$ & $160(77.3)$ & $100(62.5)$ & $60(37.5)$ & $120(85.1)$ & $75(62.5)$ & $45(37.5)$ \\
\hline & 全 & 本人数 & 348 & $226(64.9)$ & $122(35.1)$ & 207 & $134(64.7)$ & $73(35.3)$ & 141 & $92(65.2)$ & $49(34.8)$ \\
\hline
\end{tabular}


表 2 調查対象者の年齢, BMI, 血清成分値および総カロテノイド值

\begin{tabular}{|c|c|c|c|c|c|c|c|}
\hline \multirow[b]{2}{*}{ 項 } & \multirow[b]{2}{*}{ 目 } & 全 & 体 & \multicolumn{2}{|c|}{ 技術系従業員 } & \multicolumn{2}{|c|}{ 事務系従業員 } \\
\hline & & 尿酸正常値者 & 尿酸高値者 & 尿酸正常値者 & 尿酸高値者 & 尿酸正常値者 & 尿酸高値者 \\
\hline 平均年齢 & 歳 & $53.1(5.0)$ & $51.6(5.7) *$ & $53.6(4.7)$ & $51.8(5.5) *$ & $52.4(5.1)$ & $51.4(6.0)$ \\
\hline $\mathrm{BMI}$ & $\mathrm{kg} / \mathrm{m}^{2}$ & $22.9(2.4)$ & 24. $0(2.9) * * *$ & $22.9(2.5)$ & $23.4(2.5)$ & $22.9(2.3)$ & 24.9 (3. 3$) * * *$ \\
\hline 総了儿久示口ール & $\mathrm{mg} / \mathrm{dl}$ & $209(30)$ & $222(34) * * *$ & $208(29)$ & $220(36) * *$ & $211(30)$ & $224(32) *$ \\
\hline HDL-JUス次-ル & $\mathrm{mg} / \mathrm{dl}$ & $56.1(14.1)$ & $54.9(17.8)$ & $57.0(15.1)$ & $56.7(16.0)$ & 54. $6(12.2)$ & $52.3(12.9)$ \\
\hline 中性脂肪 & $\mathrm{mg} / \mathrm{dl}$ & $107(61)$ & $162(149) * * *$ & $103(61)$ & $162(174) * * *$ & $113(62)$ & $162(105) * * *$ \\
\hline 尿酸 & $\mathrm{mg} / \mathrm{dl}$ & $5.5(0.9)$ & $7.9(0.8) * * *$ & $5.4(1.0)$ & $8.0(0.8) * * *$ & $5.7(0.8)$ & $7.8(0.7) * * *$ \\
\hline 尿素窒素 & $\mathrm{mg} / \mathrm{dl}$ & 15. $7(3.5)$ & 14. 6 (3. 2)** & $15.8(3.5)$ & 14. 7 (3. 4$) *$ & 15.4 (3. 4 ) & $14.5(2.9)$ \\
\hline 次手ン & $\mathrm{mg} / \mathrm{dl}$ & $1.0(0.1)$ & $1.1(0.2) * * *$ & $1.0(0.1)$ & $1.1(0.2) * * *$ & $1.1(0.1)$ & $1.2(0.1) *$ \\
\hline \EグロビンA1 & $\%$ & $5.0(0.5)$ & $5.1(0.6)$ & $4.9(0.5)$ & $5.0(0.6)$ & $5.2(0.3)$ & $4.8(0.4)$ \\
\hline GOT活性 & $I U / L$ & $20.7(6.0)$ & $25.4(11.7) * * *$ & $20.2(5.7)$ & 25. $4(12.5) * * *$ & $21.6(6.4)$ & $25.5(10.6) * *$ \\
\hline GPT活性 & $I U / L$ & $20.8(10.6)$ & $28.0(20.9) * * *$ & $19.8(9.1)$ & $27.6(18.7) * * *$ & $22.1(12.4)$ & $28.5(24.0) *$ \\
\hline r-GTP活性 & $\mathrm{IU} / \mathrm{L}$ & $30.4(25.4)$ & 53. $7(51.9) * * *$ & $30.3(26.0)$ & $56.5(59.7) * * *$ & $30.6(25.0)$ & $49.1(37.6) * * *$ \\
\hline$\alpha-$ 加于y & $\mu \mathrm{mol} / \mathrm{L}$ & $0.092(0.103)$ & $0.083(0.087)$ & $0.090(0.112)$ & $0.080(0.103)$ & $0.096(0.088)$ & $0.074(0.054)$ \\
\hline$\beta$-加テソ & $\mu \mathrm{mol} / \mathrm{L}$ & $0.530(0.549)$ & $0.444(0.451)$ & $0.532(0.602)$ & $0.487 \quad(0.534)$ & $0.526(0.463)$ & $0.381(0.281) *$ \\
\hline りコピン & $\mu \mathrm{mol} / \mathrm{L}$ & $0.440(0.276)$ & $0.424(0.294)$ & $0.406(0.303)$ & $0.396(0.318)$ & $0.490(0.224)$ & $0.465(0.251)$ \\
\hline 総加于值 & $\mu \mathrm{mol} / \mathrm{L}$ & $1.062(0.780)$ & $0.952(0.702)$ & $1.028(0.851)$ & $0.973(0.809)$ & $1.112(0.663)$ & $0.920(0.509)$ \\
\hline 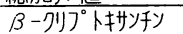 & $\mu \mathrm{mol} / \mathrm{L}$ & $0.169(0.155)$ & $0.159(0.148)$ & $0.198(0.187)$ & 0.19 । $(0.179)$ & $0.126(0.069)$ & $0.110(0.057)$ \\
\hline ゼア抽ンチン＆んテイソ & $\mu \mathrm{mol} / \mathrm{L}$ & $0.983(0 . .62)$ & $1.020(0.504)$ & $0.994(0.340)$ & $1.044(0.605)$ & $0.968 \quad(0.393)$ & $0.984(0.298)$ \\
\hline プ吅“夘次 & $\mu \mathrm{mol} / \mathrm{L}$ & $0.791(0.720)$ & $0.687 \quad(0.612)$ & $0.820(0.811)$ & $0.768(0.724)$ & $0.748(0.565)$ & $0.565(0.364) *$ \\
\hline 総加亏人仆“値 & $\mu \mathrm{mol} / \mathrm{L}$ & 2. $241(1.046)$ & 2. 158 (1.099) & $2.245(1.115)$ & $2.233(1.282)$ & $2.236(0.943)$ & $2.045(0.746)$ \\
\hline (チ)ール & $\mu \mathrm{mol} / \mathrm{L}$ & $2.777(0.606)$ & 3. $220(0.725) * * *$ & $2.849(0.676)$ & $3.414(0.714) * * *$ & $2.672(0.469)$ & $2.929(0.646) * *$ \\
\hline$\alpha-卜]>I)-\|$ & $\mu \mathrm{mol} / \mathrm{L}$ & $26.19(6.47)$ & $29.62(7.62) * * *$ & $26.31(5.50)$ & $30.10(8.59) *$ & $26.01(7.70)$ & $28.91(5.92) *$ \\
\hline 全体人数 & & 226 & 122 & 134 & & 92 & 49 \\
\hline
\end{tabular}

平均値(標準偏差)

平均値の差の検定 (Student $\mathrm{t}$-test) $\quad * \mathrm{p}<0.05 、 * * \mathrm{p}<0.01 、 * * * \mathrm{p}<0.001$

表 3 尿酸高值者に対する自覚症状および食生活習慣のオッズ比

\begin{tabular}{|c|c|c|c|c|}
\hline \multirow[b]{2}{*}{ 項 } & \multirow{2}{*}{ 区 分 } & \multicolumn{3}{|c|}{ オッズ比(95\%信頼区間) } \\
\hline & & 体 & 技術系從業員 & 事務系従業貝 \\
\hline 脈の乱れや動悸 & 有／無 & $1.43(0.76-2.70)$ & $1.56(0.68-3.58)$ & $1.43(0.50-4.11)$ \\
\hline 侯の乾き & 有／無 & $1.68(0.94-3.00)$ & $1.84(0.83-4.08)$ & $1.71(0.70-4.18)$ \\
\hline 夜小便に起きる & 有／無 & 1. $42(0.84-2.38)$ & 1. $22(0.61-2.44)$ & 2. $13(0.89-5.13)$ \\
\hline 体がだるく感ずる & 有／無 & 1. $66(1: 02-2.73) *$ & 1. $97(1.01-3.86) *$ & $1.17(0.53-2.60)$ \\
\hline 異常な疲れを感ずる & 有／無 & $1.50(0.89-2.53)$ & 1. $89(0.94-3.82)$ & $1.15(0.49-2.69)$ \\
\hline イライラする & 有／無 & 2. $23(1.32-3.77) *$ & $2.03(1.03-4.11) *$ & 2. $35(1.02-5.43) *$ \\
\hline 相談相手が居る & 有 /無 & $1.05(0.49-2.27)$ & $1.77(0.72-4.38)$ & $0.24(0.04-1.47)$ \\
\hline 家族亡同居 & いいえ/はい & $1.57(0.74-3.33)$ & 1. $36(0.49-4.38)$ & $1.84(0.58-5.85)$ \\
\hline 運動習慣 & 有／無 & $0.93(0.57-1.54)$ & $0.70(0.36-1.37)$ & $1.56(0.66-3.67)$ \\
\hline よく眠れる & いいえ/はい & $1.45(0.88-2.38)$ & $1.26(0.65-2.44)$ & $1.64(0.73-3.71)$ \\
\hline 夜食をよく食べる & はい/いいえ & $0.69(0.29-1.68)$ & $0.52(0.18-4.56)$ & $1.67(0.30-9.04)$ \\
\hline 外食が多い & はい/いいえ & $2.58(1.32-5.03) *$ & $1.86(0.51-6.43)$ & $2.62(1.16-5.93) *$ \\
\hline 野菜類をあまり食べない & はい/いいえ & 1. $29(0.65-2.57)$ & $1.08(0.43-2.72)$ & $1.66(0.53-5.20)$ \\
\hline 魯より肉をよく食べる & はい/いいえ & $1.04(0.58-1.87)$ & $1.09(0.51-2.34)$ & $1.33(0.50-3.52)$ \\
\hline たばこを吸う & はい/いしえ & $1.01(0.59-1.73)$ & $1.13(0.54-2.35)$ & $0.79(0.34-1.84)$ \\
\hline お酒をよく飲む & リいいえ & $2.50(1.26-4.96) *$ & $3.02(1.24-7.31) *$ & 2. $09(0.62-7.07)$ \\
\hline 全体人数 & & 348 & 207 & 141 \\
\hline
\end{tabular}

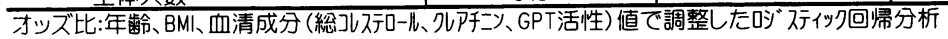

$*: p<0.05$

尿酸正常値者の平均年齢に比して低い傾向を示し た。BMI は技術系・事務系共に尿酸正常值者に 比して尿酸高值者で高く, 特に, 事務系従業員で は有意に高い傾向を認めた。血清成分值では技術 系事務系共に血清総コレステロール, 中性脂肪, クレアチニン，血清酵素活性 (GOT, GPT, $\gamma$ GTP）等は尿酸高值者で尿酸正常値者に比して 有意に高く,一方，へモグロビン Alc 值には相 違を認めなかった。 $\mathrm{AC}, \mathrm{BC}, \mathrm{LY}$ のカロテン值 や CR，PVA などのカロテノイド值では技術系 事務系共に尿酸高值者で低く, 逆に RE, AT で
は尿酸高值者が高い成績を得た。

尿酸高值者に対する自覚症状および食生活習慣 のオッズ比を年齢, BMI, 総コレステロール, クレアチニン, GPT で調整したロジスティック 回帰分析の結果を表 3 に示す。技術系従業員の尿 酸高値者の自覚症状では「体がだるく感ずる」, 「イライラする」のオッズ比は約 2.0 と尿酸正常 者に比して有意に高い傾向を示し，一方で尿酸高 值者の「運動習慣あり者」のオッズ比が 0.7 と低 い傾向を得た。事務系従業員では「夜小便に起き る」,「イライラ寸る」のオッズ比が 2.0 以上と尿 
表 4 尿酸高値者に対する血清カロテノイド值, レチノール， $\alpha$-トコフェノール0オッズ比

\begin{tabular}{|c|c|c|c|c|c|c|c|}
\hline \multirow{2}{*}{ 項 } & \multirow{2}{*}{ 目 } & \multicolumn{3}{|c|}{ モテル1:オッズ比(95\%信頼区間) } & \multicolumn{3}{|c|}{ モデル2:オッズE゙(95\%信頼区間) } \\
\hline & & 低値者群 & 中間値者群 & 高値者群 & 低値者群 & 中間値者群 & 高値者群 \\
\hline$\alpha$-カ口テン & $\mu \mathrm{mol} / \mathrm{L}$ & 1.0 & $1.12(0.65-1.92)$ & $0.91(0.53-1.58)$ & 1.0 & $0.92(0.50-1.69)$ & $0.68(0.36-1.29)$ \\
\hline$\beta$-カロテン & $\mu \mathrm{mol} / \mathrm{L}$ & 1. 0 & $0.91(0.53-1.55)$ & $0.76(0.44-1.31)$ & 1. 0 & $0.64(0.34-1.20)$ & $0.49(0.25-0.96) *$ \\
\hline リコピン & $\mu \mathrm{mol} / \mathrm{L}$ & 1. 0 & $0.92(0.54-1.57)$ & $0.77(0.44-1.33)$ & 1.0 & $0.81(0.44-1.48)$ & $0.58(0.31-1.10)$ \\
\hline 総加玄值 & $\mu \mathrm{mol} / \mathrm{L}$ & 1. 0 & $0.84(0.49-1.43)$ & $0.80(0.46-1.38)$ & 1.0 & $0.65(0.35-1.20)$ & $0.52(0.26-1.02)$ \\
\hline ßクリリプトキ决ン & $\mu \mathrm{mol} / \mathrm{L}$ & 1. 0 & $1.06(0.62-1.81)$ & $0.92(0.53-1.59)$ & 1.0 & $0.71(0.39-1.30)$ & $0.70(0.36-1.35)$ \\
\hline ゼアキサンチソ＆ルテイソ & $\mu \mathrm{mol} / \mathrm{L}$ & 1.0 & $1.01(0.58-1.77)$ & $1.26(0.72-2.19)$ & 1.0 & $0.89(0.48-1.64)$ & $0.85(0.44-1.62)$ \\
\hline プロビ夘A & $\mu \mathrm{mol} / \mathrm{L}$ & 1. 0 & $1.06(0.62-1.81)$ & $0.80(0.46-1.38)$ & 1. 0 & $0.86(0.46-1.59)$ & $0.53(0.27-1.06)$ \\
\hline 総加テハイド値 & $\mu \mathrm{mol} / \mathrm{L}$ & 1. 0 & $0.77(0.45-1.34)$ & $0.90(0.52-1.54)$ & 1.0 & $0.67(0.36-1.25)$ & $0.57(0.29-1.14)$ \\
\hline にチノール & $\mu \mathrm{mol} / \mathrm{L}$ & 1. 0 & 2. $12(1.12-4.00)$ & * 6.04 (3. 22-11.32) & 1.0 & $1.82(0.92-3.61)$ & 4. $45(2.24-8.86) *$ \\
\hline$\left.\alpha-卜] 7_{I}\right)-\|$ & $\mu \mathrm{mol} / \mathrm{L}$ & 1.0 & $1.93(1.05-3.52)$ & * $3.51(1.95-6.32)$ & 1.0 & $1.42(0.72-2.79)$ & 2. $22(1.09-4.63) *$ \\
\hline
\end{tabular}

酸正常者に比して高い傾向を示し，一方で尿酸高 值者の「相談相手がいる」者のオッズ比が 0.24 と低い傾向を示した。全体では尿酸高值者で「体 がだるく感じる」，「イライラする」のオッズ比が 尿酸正常者に比して有意に高かった。尿酸高值者 の食生活習慣については「外食が多い」,「酒をよ く飲む」に対するオッズ比が尿酸正常值者に比し て有意に多い頻度を示した。さらに, 事務系従業 員の尿酸高值者では「夜食をよく食べる」,「野菜 類をあまり食べない」，「魚より肉をよく食べる」 のオッズ比が高く, 特に「外食が多い」者では尿 酸高值者が有意に多い傾向を示した。技術系従業 員でも「外食が多い」者の割合は多い傾向を示す も「夜食をよく食べる」者のオッズ比は 0.52 と， その割合は少ない傾向を示した。また「魚より肉 をよく食べる」,「野菜類をあまり食べない」の オッズ比は 1.0 に近似し, これらの要因は高尿酸 血症の危険要因としての明らかな関連を認めな かった。

次に, 尿酸高值者に対する野菜類摄取につい て, その生体内指標である血清カロテノイド值を 用いて検討した。すなわち各血清カロテノイド值 を 3 等分し, 血清カロテノイドの低值者群におけ る尿酸正常值者と尿酸高值者とのオッズ比を 1.0 とした時, 血清カロテノイド值の中間值者群, お よび高值者群についてのオッズ比を比較した結果 を表 4 に示す。モデル 1 では年齢, 職種で調整し た結果, $\mathrm{AC} ・ \mathrm{BC} ・ \mathrm{LY}$ などの TCR や, CR・ PVA な゙ではオッズ比が 1.0 以下を示し, これ らカロテノイドを多く含有する食品攝取の多い者 では, 高尿酸血症への危険度が低い可能性が推察
された。特に年齢, 職種, 喫煙, 飲酒習慣, $\mathrm{BMI}$, 総コレステロール, クレアチニン, GPT で調整したモデル 2 では, BC 高值者群では統計 学的に尿酸高值者割合が有意に少ないことが示さ れた。一方，モデル 1,2 共に RE および AT の オッズ比は 1 以上の有意な高值を得, これらを多 く含有する食品摂取は, 高尿酸血症の危険要因と なる可能性が推察された。

\section{考察}

今回の調査対象は, $39 \sim 60$ 歳までの定期健康 診断受診者で, その結果, 精密検査を要する者, および投薬治療中者を除外した男性集団である。 同集団には定期健康診断後には保健婦, 産業医に よる個別面談指導などの健康教育が実施されてい る。当該事業場における健康診断後の事後指導 は, 健康の保持に努めるために食事内容や食生活 習慣, 運動習慣, 休養などの指導が重要視され, また, 医師の個別面談内容は, 健康診断結果に対 する二次検査受診の勧めや, 電算機使用による経 年推移に基づいた健康教育等が行われている。尿 酸は体内に増えすぎると血液や尿中で溶けきれな くなり体内で結晶化し, 溶解度の限界は血清尿酸 にして $7.0 \mathrm{mg} / \mathrm{d} l$ であり, それ以上で高尿酸血 症と言われている。今回の尿酸值判定には, 測定 方法によりカットオフ值が異なるが, 酵素法を取 り入れた自動分析機による測定方法から $7.0 \mathrm{mg} /$ $\mathrm{d} l$ 以上の者を尿酸高值者とした ${ }^{2,10)}$ 。

今回, 事務系従業員では技術系従業員に比較し て, 習慣的飲酒者の頻度が多く, 血清コレステ ロールや中性脂肪，および血清酵素活性の高値者 
や, BMI 26 以上の頻度が多かった。このこと は，技術系従業員は製鋼作業を中心とした高熱職 場での肉体的作業を主とする現場系の勤務体系に 対し, 事務系従業員は, 市街地中心部でデスク ワークを主とした軽作業であり，作業形態や勤務 内容, ストレスなどの労働環境, 特に肉体的労作 やエネルギー消費の相違によるものであることが 推察された。尿酸高值者に対する自覚症状の関連 では，技術系従業員で精神的要素が関連する「イ ライラ感」や「体がだるく感じる」疲労感など で, 高いオッズ比を示した。一方, 事務系従業員 では「イライラ感」のほか「不眠感」や「夜尿習 慣」が高オッズ比を示し, 職種別での尿酸高值者 に対する危険要因の可能性がそれぞれ示された。 高尿酸血症と職業性ストレスとの関連については 「イライラ感」,「仕事の多忙感」,「不眠感」など の項目が危険要因に挙げられている7)。このこと は, 日常生活習慣の指導上, 精神的な負荷要因に 対する軽減指導が, 高尿酸血症に対する予防対策 として重要であり, 技術系従業員では, さらに肉 体的疲労感に対する軽減指導も重要であることが 推察された。高尿酸血症は, 肥満やアルコールに よる尿酸合成促進, および尿酸のもととなるプリ ン体含有量の多い食物の高度攝取等, 日常食生活 習慣の影響が大きい生活習慣病でもある ${ }^{1,2,4 ~ 8)}$ 。 予防対策には, 特にプリン体の少ない食物攝取 や，摂取エネルギー，アルコール量に重点を置い た食生活指導が重要であり, 保健や栄養指導で は,これら食物摂取の抑制指導が課題とされ る $^{1,7,14)}$ 。

本対象者集団への健康教育などの指導では, 生 活習慣病についての総合的な指導はもちろんのこ と, 飲酒やエネルギー捸取量, 肉などのプリン体 を多く含む食物捸取など, 食生活習慣や運動習慣 などライフスタイルの改善を中心とした事後指導 が行われている。生活習慣病予防に対する食生活 習慣は, 野菜食を中心としたバランスの取れた食 生活が重要であり, 最近, 緑黄色野菜摂取の生体 内指標として知られる血清カロテノイドの指標的 意義も注目されている。本調査においても, 事務 系従業員の尿酸高値者で「野菜類をあまり食べな い」者のオッズ比が高值を示し, 特に BC や $\mathrm{AC}$
など血清カロテン値の高值者群では尿酸高值者の 割合が少ないなど，これらを多く含有する食品摂 取の増加が, 高尿酸血症抑制要因となる可能性が 推察された。

$\mathrm{BC}$ はその含有量が多い緑黄色野菜類摂取で上 昇し ${ }^{15,16)}$, 特に, 脂肪との同時摂取で上昇が大き いことが報告されている17)。一方, 高尿酸血症の 危険要因である飲酒習慣を有する者や, 肥満者で 低く ${ }^{18,19)}$, 運動習慣を有する者で高いなど20), 事 後指導の遵守を反映する可能性が大きい成績も得 ている ${ }^{12)}$ 。さらに BC は, 生活習慣病の重要なり スク要因である活性酸素やラジカルなどを捕捉す る抗酸化作用等を有し ${ }^{21,22)}$, がんや循環器疾患に 対する抑制要因としても知られている ${ }^{23,24)}$ 。これ らのことから, 事務系従業員では, $\mathrm{BC}$ を多く有 する食品摂取は高尿酸血症に対する予防要因とし ても有用であると同時に， BC は，高尿酸血症に 対する健康診断の事後指導の遵守を判断する一生 体指標としての意義も有する可能性が推察され た。

\section{結語}

定期健診男性受診者のうち尿酸高値者における 自覚症状, 食生活などの日常生活習慣の特徵など を検討した。その結果「疲労感」,「イライラ感」 のほか「喉の乾き」,「不眠感」等の自覚症状や飲 酒習慣が高尿酸血症の危険要因として，さらに， 野菜類摂取嗜好や高血清 $\mathrm{BC}$ 値が予防要因となる 可能性が推測された。

謝 辞: 本研究は, 定期従業員健診に携わる多 くの諸先生方のご協力を得て行われたものであ る。ここに関係各位に，心より深く感謝を申し上 げます。

\section{文 献}

1）山岡 孝, 板倉光夫 : 高尿酸血症の成因と病態, Medical Practice, 1064-1072, 1999.

2）蓮沼智子, 西岡久寿樹：尿酸, 日本臨牀, 57 (増刊号)： 549-551, 1999.

3）七川歓次, 武仲善孝, 川田陽一：増加している高尿酸 血症の背景, Medical Practice, 5(3) : 380-381, 1988.

4) Lanese, R. R., Gresham, G. E. and Keller, M. D. : 
Behavioral and physiolosical characteristics in hyperuricemia, JAMA, 207 : 1878-1882,1969.

5) Nishimura, T., Shimizu, T., Mineo, I. et al. : Influence of daily habits on ethanol-induced hyperuricemia, Metabolism, 43: 745-748, 1994.

6) van der Gaag, M.S., van den Berg, R., van den H., Schaafsma, G., Hendriks, H. F. : Moderate comsumption of beer, red wine and sprits has counteracting effects on plasma antioxidants in middleaged men, Eur J Clin Nutr, 54 (7) : 1243-1248, 2000.

7）小野桂子, 井奈波良一, 吉田英世, 岩田弘敏：高尿酸血 症への職業ストレスおよび食物摂取状況の関与, 日本 公衛誌, $44 ： 239-246,1992$.

8）富田眞佐子, 水野正一：痛風・高尿酸血症の疫学・死 因, Medical Practice, 16:1117-1119, 1999.

9) Tomita, M., Mizuno, S., Yamanaka, H. et al. : Does hyperuricemia affect mortality?, a prospective cohort study of Japanese male workers, J Epidemiol, 10(6) : 403-409, 2000.

10）鎌谷直之：血清尿酸, 和田 攻, 大久保昭行, 永田直一, 矢崎義雄 (編), 臨床検査ガイド 2001, 2002, 240-242, 文 光堂, 東京, 2001 .

11) Ito, Y., Ochiai, J., Sasaki, R. et al. : Serum concentrations of carotenoids, retinol, and $\alpha$-tocopherol in healthy persons determined by high-performance liquid chromatography, Clin Chim Acta, 194: 131144, 1990.

12）池山真治, 伊藤宜則, 濱松昭雄, 鈴木康司, 小森義隆, 渡 邉 悟：某事業所男性従業員のへモグロビンAlc 高 值者における血清カロテノイド値の指標的意義, 日本 総合医学会誌, 28(2) : 1-8, 2001.

13）高橋善弥太：医者のためのロジスチック・Cox 回帰 入門, 19-23 頁, 日本医学館, 東京, 1997.

14）細谷龍男：高尿酸血症の合併症, Medical Practice, 16：1080-1087, 1999.
15) Olsen, J. A. : Serum levels of vitamin A and carotenoids as reflectors of nutritional status, J Natl. Cancer Res, 73 : 1439-1444, 1984.

16) Drewnowski, A., Rock, C. L., Henderson, S. A. et al. : Serum $\beta$-carotene and vitamin $\mathrm{C}$ as biomarkers of vegetable and fruit intakes in a community based sample of French adults, Am J Clin Nutr, 65 : 1796-1802, 1997.

17) Prince, M. R. and Frisoli, J. K.: Beta-carotene accumulation in serum and skin, Am J Clin Nutr, 57 : 175-181, 1993

18) Stryker, W. S., Kaplan, L. A., Stein, E. A. et al. : The relation of diet, cigarette smoking, and alcohol consumption to plasma beta-carotene and alphatocopherol, Am J Epidemiol, 127 : 283-290, 1988.

19) Ito, Y., Shima, Y., Ochiai, J. et al. : Effects of the consumption of cigarettees, alcohol and foods on serum concentrations of carotenoids, retinol and tocopherols in healthy inhabitants living in a rural area of Hokkaido, Jpn J Hyg, 46: 874-882, 1991.

20）鈴木康司, 伊藤宜則, 落合潤一, 高崎昭彦, 市野直浩, 大 谷元彦：住民健診受診者に打ける運動習慣と肥満度, 血清脂質成分値との関連, 健誌, $27: 380-388,2000$.

21) Burton, G. W. and Ingold, K. U. : $\beta$-Carotene: an unusual type of lipid antioxidant, Science, 224 : 569-573, 1984.

22) Bendich, A. and Olsen, J. A. : Biological actions of carotenoids, FASEB J, 3 : 1927-1932, 1987.

23) Ziegler, R. G. : Vegetables, fruits and carotenoids and the risk of cancer, Am J Clin Nutr, 53 : 251 S259 S, 1991.

24) van Poppel, G. and Goldbohm, R. A. : Epidemiologic evidence for $\beta$-carotene and cancer prevention, Am J Clin Nutr, 62 : 1393 S-1402 S, 1995. 


\title{
Summary
}

\section{Relationship between Hyperuricemia and both Subjective Symptoms and Life-styles among Male Industrial Workers}

\author{
Shinji Ikeyama, Yoshinori Ito, Akio Hamamatsu, \\ Yoshitaka Komori, Satoru Watanabe, Nobuhiro Ushida
}

A total of 348 male workers, attending a health check-up program, were studied in order to assess the relation between hyperuricemia and both subjective symptoms and daily life-styles. The subjects consisted of 207 technical workers and 141 office workers, aged from 39 to 60 years, employed in a steel factory.

Examination of subjective symptoms showed that odds ratios of hyperuricemia were high for subjects with irritation $(2.23 ; 95 \%$ C. I., 1.32 3.77) and subjects with fatigue (1.66;95\% C. I., 1.02 2.73). Examination of lifestyles showed high odds ratios for high frequency of eating out $(2.58 ; 95 \%$ C. I., $1.32 \sim 5.03)$ and high frequency of alcohol consumption $(2.50 ; 95 \%$ C. I., 1.26 4.96). High odds ratios of hyperuricemia were found for subjects with high serum levels of retinol $(4.45 ; 95 \%$ C. I., $2.24 \sim 8.86)$ and $\alpha$-tocopherol $(2.22 ; 95 \%$ C. I., 1.09 4.63), after adjusting for age, work type, smoking status, alcohol consumption, BMI, and serum levels of total cholesterol, creatinine and GPT activity. In contrast, the odds ratio was low for subjects with high serum levels of $\beta$-carotene $(0.49 ; 95 \%$ C. I., $0.25 \sim 0.96)$.

These results indicate that certain subjective symptoms (fatigue and irritation), high frequencies of eating out, and alcohol consumption can be risk factors for hyperuricemia, and that high intake of foods rich in $\beta$-carotene (e.g., colored vegetables and fruits) may reduce the risk of hyperuricemia.

Key Words : Hyperuricemia, Subjective Symptoms, Life-style, Carotenoids, Odds Ratio 